\title{
Manufacturing of Cu-Sn foams through SDP
}

\author{
Sandro Báez-Pimiento ${ }^{1}$, Olivia Rosas-Carballar ${ }^{2}$ \\ María Elena Hernández-Rojas ${ }^{3}$
}

\author{
${ }^{1}$ Universidad Nacional de Colombia - Sede Manizales - Facultad de Ingeniería y Arquitectura - Departamento de Inge- \\ niería Industrial - Grupo de Investigación en Innovación y Desarrollo Tecnológico - Kilómetro 7, vía al Aeropuerto, \\ Manizales, C.P. 170003 - Colombia. \\ E-mail: sbaezp@unal.edu.co \\ ${ }^{2}$ Universidad Autónoma Metropolitana - Unidad Azcapotzalco - División de Ciencias Básicas e Ingeniería - Departa- \\ mento de Ingeniería de Materiales, México D.F., C.P. 02200, México. \\ E-mail: oli_placi@hotmail.com \\ ${ }^{3}$ Universidad Católica de Manizales - Facultad de Ingeniería y Arquitectura - Grupo de Investigación en Desarrollos \\ Tecnológicos y Ambientales (Gidta) - Cra. 23 No 60-63, Manizales, C.P. 170002 - Colombia. \\ E-mail: mehernandez@ucm.edu.co
}

\begin{abstract}
This work reports the processing of bronze foams manufactured by using the powder metallurgy method known as Sintering Dissolution Process. During the sintering step, a device with controlled atmosphere separated from the heating furnace was employed to avoid the quick oxidation of metal particles. The device allows to control its internal atmosphere with an inert gas avoiding the employment of a controlled atmosphere furnace (a furnace of this kind incorporates the heating and the control atmosphere systems itself). The metal used for the present study was bronze powders with a composition of $85 \% \mathrm{Cu}-15 \% \mathrm{Sn}, \sim 8.7 \mathrm{~g} / \mathrm{cm}^{3}$ in density, and particle size of $74 \mu \mathrm{m}$. Spherical carbamide $\left(\mathrm{CH}_{4} \mathrm{~N}_{2} \mathrm{O}\right)$ with particle size of $\sim 1 \mathrm{~mm}$ was chosen as Space Holder Particles (SHP). The maximum porosity $P_{f}$ and minimum density $\rho_{f}$ values were $42.8 \%$ and $3.61 \mathrm{~g} / \mathrm{cm}^{3}$, respectively. As the carbamide content is increased, the bronze powders content is diminished and consequently $P_{f}$ is increased and $\rho_{f}$ is diminished, as it would logically be expected. The minimum obtained $\rho_{f}$ value corresponds only to $41.4 \%$ of the bronze density $\left(\sim 8.7 \mathrm{~g} / \mathrm{cm}^{3}\right)$. On the other hand, the plots of stress $\sigma$ vs strain $\varepsilon$ indicated $\sigma_{\max }$ values between 26.86 and $8.45 \mathrm{MPa}$ (20 and 35\%vol. of carbamide, respectively). These obtained values indicate a good metallurgical bond among particles, caused by the uniaxial compression step and sintering at the correct $T_{s}$, previously determined $\left(580^{\circ} \mathrm{C}\right)$. The $\sigma_{\max }$ decreases as the SHP content increases, which is due to a significant amount of porosity generated by the SHP dissolution and by the inclusion of void spaces among the metal particles; the both of them imply a lower area supporting the load, and consequently a reduction in $\sigma_{\max }$ value for the samples. The results are interpreted in terms of increase and decrease of the carbamide and the bronze powder content in the sample, respectively.
\end{abstract}

Keywords: Bronze foams, sintering dissolution process, cellular metals, metal foams.

\section{INTRODUCTION}

The technology of powder metallurgy (PM) has been highlighted as a source in the making of new materials and light parts providing a reduction of production costs mainly in the automobile industry. Currently, the PM has resulted to be competitive regarding the casting, forging and machining processes particularly employed in the manufacture of complex metallic parts, and which can be made using the PM processes. Nowadays, the PM processes have been used to fabricate porous metals. These porous metals (also called cellular metals) with high porosity have been developed to use them as new functional materials, given that these materials present a unique combination of physical and chemical properties, which can be derived from their cellular structure [1]. Porous metals show increasing potential for applications in a wide range of structural and functional products, due to their exceptional mechanical, thermal, acoustic, electrical and chemical properties $[2,4]$. Cellular metals can be manufactured through a great variety of methods, including processes with the metal in the solid, liquid and gaseous state. Commonly used methods based on the solid state involve the incorporation of a removable space holder phase; e. g. a conventional powder metallurgy (PM) methods, involving removable particles blended with those of metal's [5,6]. Zhao and Sun [7] 
developed a technique to manufacture open-cell foams at low cost using the PM route, known as the sintering and dissolution process (SDP). To date, the SDP method has been used to obtain foams, which widely show good properties and interconnected pores (important for any application where a large superficial area of the foam is necessary). The SDP method consists of four stages: i) Mixing metal powder with the Space Holder Particles (SHP), ii) Compacting the mixture to obtain a green compact, iii) Dissolution of the SHP with an appropriate solvent to obtain a cellular metallic structure, and iv) Sintering of the cellular metallic structure to produce metallurgical bond among the metallic powders. In the present work, the SDP route is employed to fabricate porous bronze (with increasing porosity to obtain closed pore and open pore foams) with regular pore size and good mechanical properties, using bronze powders and carbamide as SHP.

\section{MATERIALS AND EXPERIMENTAL TECHNIQUES}

The metal powder used in the present study to produce the main framework of the foams was bronze powder with $99.0 \%$ purity and particle size of $\sim 74 \mu \mathrm{m}$ provided by "Stannum de México $S$. A." (Fig. 1a). As it can be seen in the figure, the particles had a roughly spherical shape. The bronze particles were previously cleaned with nitric acid according to ASTM standard G1 [12] to eliminate the impurities and corrosion products on the particle surface and to enhance the bond among metal particles. In order to increase porosity and to create an interconnected cells structure, spherical $\mathrm{CH}_{4} \mathrm{~N}_{2} \mathrm{O}$ provided by "Droguería Cosmopolita S. A. de C. V." with particle size of $\sim 1 \mathrm{~mm}$ was selected as the SHP (Fig. 1b). An SHP with a variable size is employed due to the increase of the stiffness and the strength of the foams with multi-size cells [13].
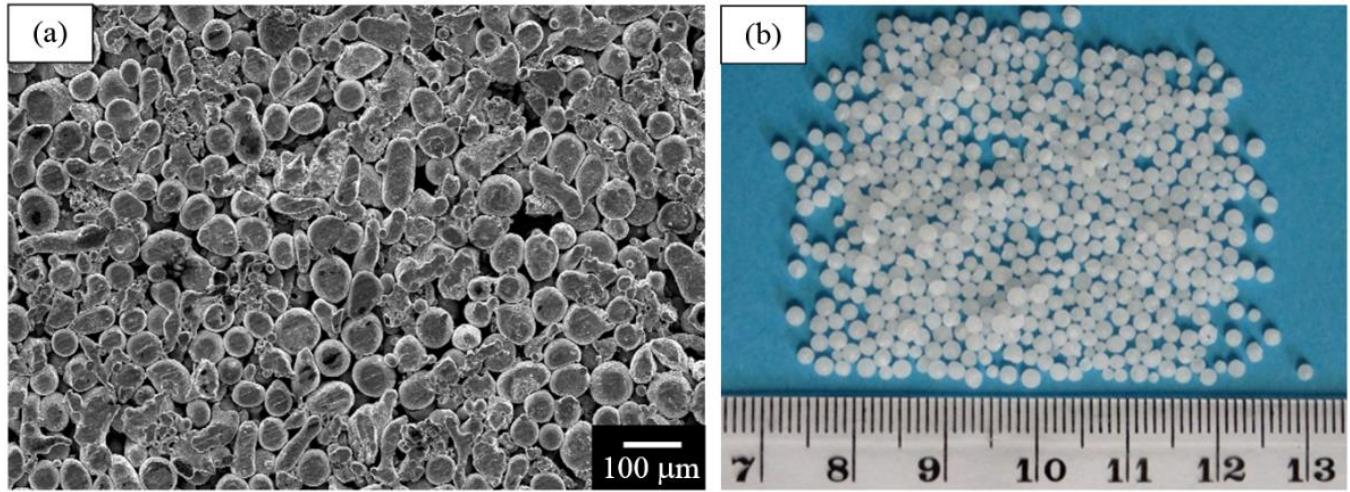

Figure 1: a) SEM secondary electron images of sintered bronze powders showing a particle size of $\sim 74 \mu \mathrm{m}, \mathrm{b})$ optical image of spherical $\mathrm{CH}_{4} \mathrm{~N}_{2} \mathrm{O}$ with a size of $1 \mathrm{~mm}$, approximately.

The total weight of bronze powder and $\mathrm{CH}_{4} \mathrm{~N}_{2} \mathrm{O}$ granules mixture varied between $\sim 12$ and $\sim 15 \mathrm{~g}$ in all samples. The mixing of the bronze powders and $\mathrm{CH}_{4} \mathrm{~N}_{2} \mathrm{O}$ granulates was performed in an agate mortar for 30 min. With the aim of ensuring good adhesion of bronze powders, $2 \%$ vol. of ethanol was sprayed on $\mathrm{CH}_{4} \mathrm{~N}_{2} \mathrm{O}$ granules before the mixing stage to obtain a sticky surface. Then, for all samples, the mixture was put into a steel mold and uniaxially pressed at $400 \mathrm{MPa}$ for $30 \mathrm{~min}$. to produce cylindrical green compacts with $16 \mathrm{~mm}$ in diameter and $\sim 14 \mathrm{~mm}$ in length. Specimens containing $100 \%$ vol. of bronze powders compacted at 400 $\mathrm{MPa}$ were sintered at temperatures from $580{ }^{\circ} \mathrm{C}$ to $640{ }^{\circ} \mathrm{C}$ (with increments of $20^{\circ} \mathrm{C}$ each experiment) for 180 minutes in order to determine the optimum sintering temperature, $T_{s}$. The spherical $\mathrm{CH}_{4} \mathrm{~N}_{2} \mathrm{O}$ and bronzefoams morphology were characterized using a digital camera (Sony 3D) to determine the obtained granules' form and pore distribution, respectively. Scanning Electron Microscopy (Jeol JSM 6610 HLV) operated at 20 $\mathrm{keV}$ was used to determine the quality of the metallurgical bond among the metallic powders. For each specimen, the weights of the initial bronze powders, $\mathrm{CH}_{4} \mathrm{~N}_{2} \mathrm{O}$ granules, bronze $/ \mathrm{CH}_{4} \mathrm{~N}_{2} \mathrm{O}$ green compact and the resultant bronze foam before and after sintering processes were measured using an Ohaus balance with an accuracy of $0.1 \%$. Using these data, the green compact porosity $P_{c}$, and foam porosity $P_{f}$, were determined through the equations 1 to 3 [8-11]. Where, $\rho_{c}$ is the green compact density, $\rho_{t h}$ is the compact theoretical density, $\rho_{B}$ is the bronze density, $W_{B}$ is the bronze weight fraction in the mixture, $\rho_{S H P}$ is the carbamide density and $\rho_{f}$ is the foam density. The densities of green compact and foams were determined using the conventional equation $\rho=\mathrm{M} / \mathrm{V}(\mathrm{M}=$ mass, $\mathrm{V}=$ Volume $)$. 


$$
\begin{aligned}
P_{c} & =1-\frac{\rho_{c}}{\rho_{\text {th }}} \\
\rho_{\text {th }} & =\left(\rho_{\text {metal }} * W_{\text {metal }}\right)+\left(\rho_{\text {SHP }} *\left(1-W_{\text {metal }}\right)\right) \\
P_{f} & =1-\frac{\rho_{f}}{\rho_{\text {metal }}}
\end{aligned}
$$

\section{RESULTS AND DISCUSSION}

Following the procedure to determine the optimum sintering temperature, above described, $T_{s}$ was found to be $580{ }^{\circ} \mathrm{C}$ (Fig. 2a), given that at this temperature the best particle bonding was observed in the SEM analysis as it is showed in the particles group enclosed by the yellow circles. At temperatures of 600,620 and $640{ }^{\circ} \mathrm{C}$ poor particle bonding was found as it is observed in the Fig. $2 \mathrm{~b}-\mathrm{d}$. Since temperatures above $580{ }^{\circ} \mathrm{C} \mathrm{did} \mathrm{not}$ result in substantial bonding, the temperature of $580{ }^{\circ} \mathrm{C}$ was selected for all subsequent sintering treatments, given that at this temperature a significant densification of the structure had taken place on the sintering.
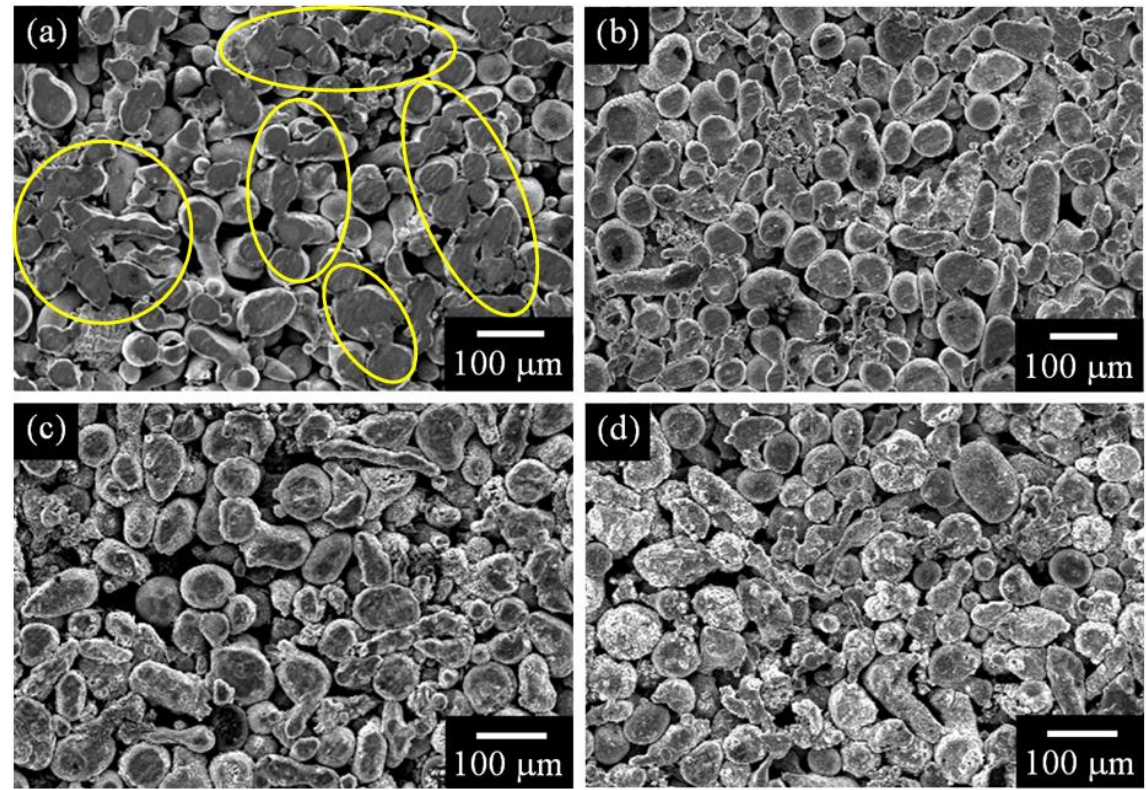

Figure 2: a) SEM secondary electron images showing the superficial bonding of compacted bronze particles sintered at temperatures of: a) $580{ }^{\circ} \mathrm{C}$, b) $\left.600{ }^{\circ} \mathrm{C}, \mathrm{c}\right) 620^{\circ} \mathrm{C}$, and d) $640{ }^{\circ} \mathrm{C}$.

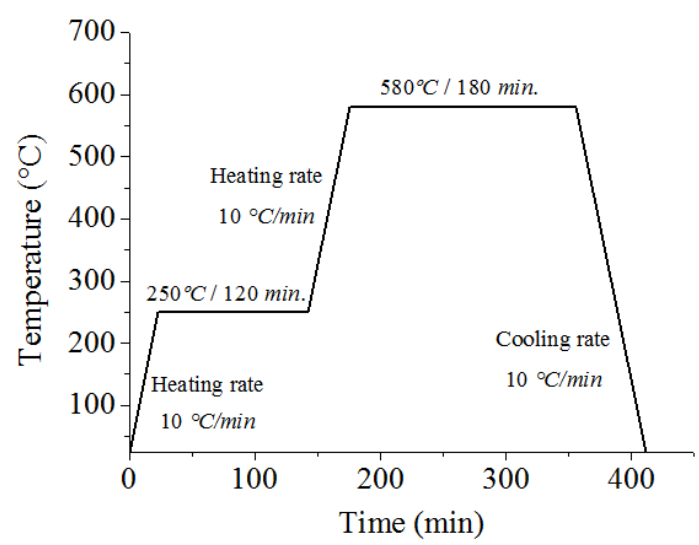

Figure 3: Thermal cycle used in the bronze foams carbamide removal and metal particles sintering processes. 
In the green compacts, the carbamide fraction was removed maintaining the samples at a temperature of $250{ }^{\circ} \mathrm{C}$ for two hours. In all cases, the stage of carbamide removal was carried out before the sintering stage and employing a controlled atmosphere device [14], in a total heat treatment of $\sim 6.9$ hours each experiment (Figure 3 shows the heating cycle employed in this work). The image of Figure 4a shows the device with controlled atmosphere being used for the carbamide removal and the metal particles sintering processes. The image of Figure $4 \mathrm{~b}$ shows the configuration device/furnace which consists in placing the device into the conventional vertical electrical furnace, as it was employed in the present work. Figure 5 shows the series of bronze foams containing from 80 to $65 \%$ vol. of bronze powders, formed by using spherical $\mathrm{CH}_{4} \mathrm{~N}_{2} \mathrm{O}$ with diameter of $\sim 1 \mathrm{~mm}$ after the sintering process. Macroscopically, the sample presented a regular pores distribution (it implies a regular carbamide distribution in the sample), which results in bronze foams with a highly homogeneous framework, as it is required for reliable measurements of mechanical properties in this kind of material.
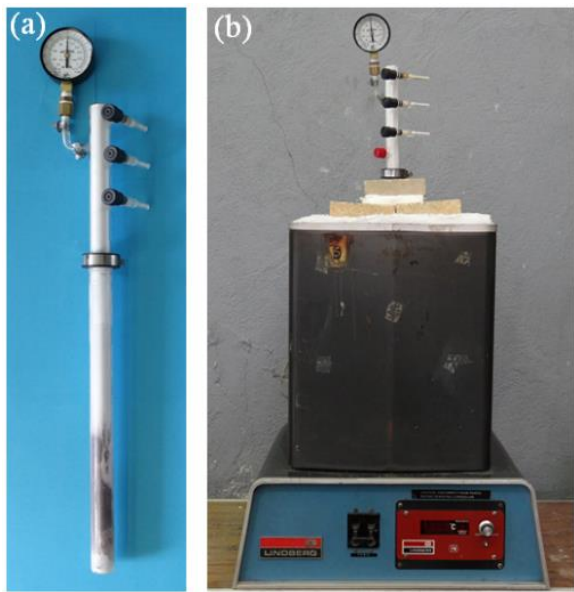

Figure 4: a) Image of the device with controlled atmosphere of inert gas fabricated in our laboratory, and b) Device/furnace configuration used for the sintering processes in the present work.

The sintering processes of the green foams were carried out in two steps following the heating plot of Figure 3 and using the device with controlled atmosphere in the sintering step and proposed in [14] (the device consists of two chambers: an upper chamber for the atmosphere control and a lower chamber for the sintering processes which are coupled by a sealed system and it is placed into any conventional vertical electric furnace. The device allows the control of its internal atmosphere and it is separated from the heating furnace, avoiding the employment of an expensive controlled atmosphere furnace and reducing the production costs of metal components). Step I, the device containing the sample was put into a vertical electrical furnace and the temperature was increased from 25 to $250{ }^{\circ} \mathrm{C}$ at a heating rate of $10{ }^{\circ} \mathrm{C} / \mathrm{min}$; the samples were held at $250{ }^{\circ} \mathrm{C}$ for 120 min to eliminate the carbamide contained in the green compact. Step II, the temperature was increased from 250 to $580{ }^{\circ} \mathrm{C}$ at a heating rate of $10{ }^{\circ} \mathrm{C} / \mathrm{min}$ and the samples were held at this temperature for $180 \mathrm{~min}$ to form a metallurgical bond among the bronze powder particles. Finally, the samples were cooled until $25{ }^{\circ} \mathrm{C}$ at a heating rate of $10{ }^{\circ} \mathrm{C} / \mathrm{min}$. The bronze foams obtained were finely polished with a silicon carbide paper in order to obtain a length/diameter ratio of 0.8, as required by E9-89a ASTM standard "Standard practice for compression testing of metallic materials at room temperature" [15]. The final dimensions of the bronze foams were also measured to determine their volume and density.

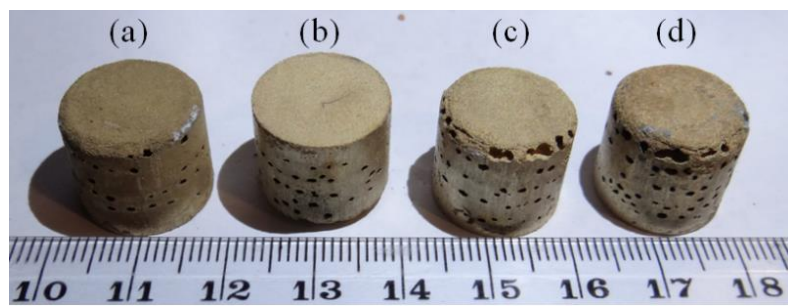

Figure 5: Image of a bronze foams series after the sintering processes, manufactured through the SDP: a) 80, b) 75 , c) 70 and e) $65 \%$ vol. of bronze powders. 
Figure 6 shows, as a function of the bronze powder content in the samples, the changes in the compact theoretical density $\rho_{t h}$, green compact density $\rho_{c}$ and foam density $\rho_{f}$. In this plots, the $\rho_{t h}, \rho_{c}$ and $\rho_{f}$ increased with the increasing metal powder content. The increase in the $\rho_{t h}$ is explained in terms of the higher value of the bronze density $\left(8.7 \mathrm{~g} / \mathrm{cm}^{3}\right)$ compared to carbamide density $\left(1.32 \mathrm{~g} / \mathrm{cm}^{3}\right)$. Given that the proportion of metal in the compact increases, the $\rho_{t h}$ increases. On the other hand, the increase in the $\rho_{c}$ results to be lower than the $\rho_{t h}$, this reduction is caused by two reasons: i) the lower density value of the carbamide compared to metal, and ii) the empty spaces inside the compact bronze/carbamide and located around the contact points among bronze/bronze particles, carbamide/carbamide granules and bronze/carbamide particles and granules, respectively. In the Figure 6 an increase in the $\rho_{f}$ is showed, which is attributed to two decreases in the empty spaces: i) the diminishing of the empty spaces inside the compact bronze/carbamide, and ii) the diminishing of the empty spaces left by the carbamide granules after their leaching. The reduction in the difference between $\rho_{c}$ and $\rho_{f}$ curves (from 0.53 at $60 \%$ Vol. to 0.27 at $80 \% \mathrm{Vol}$ of metal particles), when the bronze content increase, is mainly attributed to the decrease of carbamide content. As the carbamide content is diminished, the empty spaces left by the carbamide are diminished, the metal content is increased, and consequently $\rho_{f}$ is increased. The minimum obtained $\rho_{f}$ value was $3.7 \mathrm{~g} / \mathrm{cm}^{3}$, which corresponds to only $42.5 \%$ of the bronze density $\left(8.7 \mathrm{~g} / \mathrm{cm}^{3}\right)$.

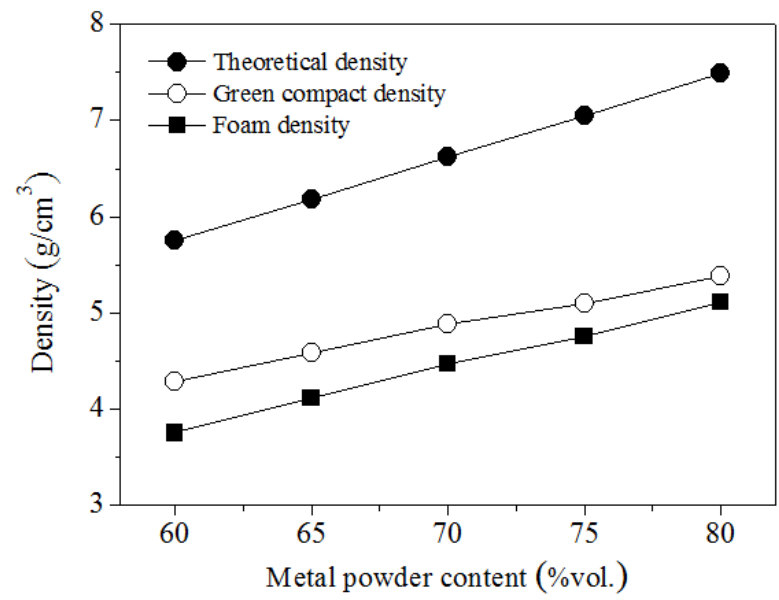

Figure 6: Plot of changes in the compact theoretical density $\rho_{t h}$, green compact density $\rho_{c}$ and foam density $\rho_{f}$. Three as a function of the bronze powders content in the samples.

Figure 7 shows, as a function of the bronze powder content in the samples, the changes in the green compact porosity $P_{c}$, and foam porosity $P_{f}$. In this plot, the $P_{c}$ gradually increases from $25.5 \%$ to $28.1 \%$ when the metal content is increased from $60 \%$ to $80 \%$.

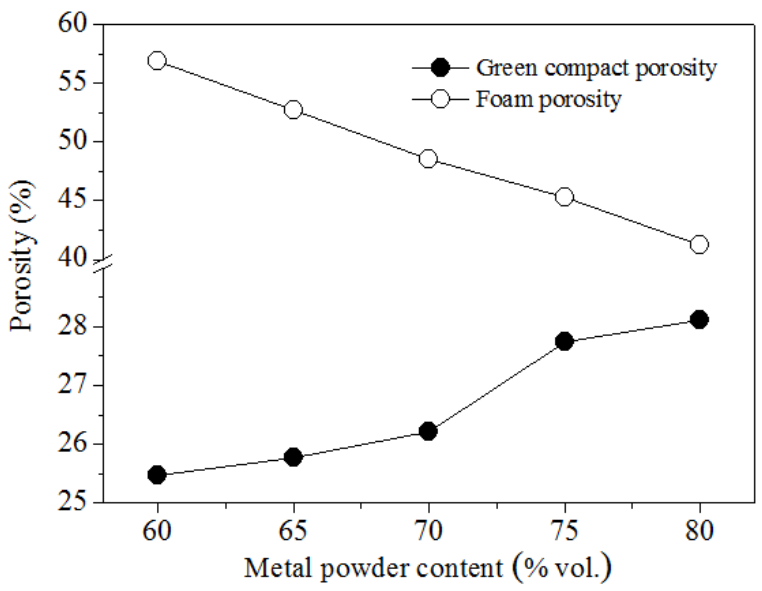

Figure 7: Plot of changes in the compacts porosity $P_{c}$ and foams porosity $P_{f}$. Both as a function of the bronze powders content. 
This increase is attributed to that the replacers metal particles of carbamide granules introduce empty spaces among bronze/bronze particles. On the other hand, $P_{f}$ decreased with the increase of the metal content. The decrease in $P_{f}$ is explained by the higher volume of metal powder added in the sample; as in the sample the content of metal powder increases and the content of carbamide granules decreases, the $\rho_{f}$ increases.

\section{CONCLUSIONS}

Metallic foams containing from 60 to $80 \%$ vol. of bronze powders were successfully produced by the sintering dissolution process and utilizing carbamide as space holder particles.

The $T_{s}$ of $580^{\circ} \mathrm{C}$ was the optimum temperature to produce bronze foams with good metallurgical bond among its particles as it is observed in the SEM images, which indicates that the device's internal atmosphere was successfully controlled.

A highly porous structure was obtained for the sample with $40 \%$ vol. of carbamide which resulted to be $\sim 57 \%$. On the other hand, the minimum obtained $\rho_{f}$ value was $3.7 \mathrm{~g} / \mathrm{cm}^{3}$, which corresponds to only $42.5 \%$ of the bronze density $\left(8.7 \mathrm{~g} / \mathrm{cm}^{3}\right)$.

The results presented here indicate that the use of SDP, employing a device with controlled atmosphere separated from the heating furnace in the sintering step, is an excellent method to obtain bronze foams with homogeneous pore distribution and low densities.

\section{ACKNOWLEDGMENTS}

S. Báez-Pimiento would like to acknowledge Dirección de Investigación Sede Manizales DIMA de la Universidad Nacional de Colombia for the financial support through the Projects 23139 "Fabricación de espumas metálicas a base de zinc (Zn), con poros interconectados, mediante la técnica de infiltración de rellenos removibles" and 34884 "Obtención y caracterización de Al-Si12 celular para posibles aplicaciones en absorción de energía bajo impacto". Moreover, MEHR and SBP thank the SNI for the distinction granted and the stipend received. Refugio-García E., Cuauhtémoc-Cuautle J.P.T., Garfias-García E., López-Hernández J.J. and Arias-Paniagua J. from UAM-Azcapotzalco; Rentería-Alcántara M.A. from UAM-Iztapalapa; Hernández-Cortes S. and Díaz-Gonzalez R.C. from ININ-México; and López-Valencia A. are also acknowledged for their technical support.

\section{BIBLIOGRAPHY}

[1] DAVIES, G.J., ZHEN, S., "Metallic foams: their production, properties and applications", Journal of Materials Science, v. 18, n.7, pp. 1899-1911, July 1983.

[2] GIBSON, L.J., ASHBY, M.F, Cellular Solids: Structure and Properties, Cambridge-United Kingdom, Cambridge University Press, 1997.

[3] BANHART, J., EIFERT, H., Metal Foams, Bremen-Germany, Verlag MIT Publishing, 1997.

[4] BANHART, J., ASHBY, M.F., FLECK, N.A., Metal Foams and Porous Metal Structures, BremenGermany, Verlag MIT Publishing, 1999.

[5] ASHBY, M.F., EVANS, A.G., et al, Metal foams: a design guide, Boston-United States, 2000.

[6] BANHART, J., "Manufacture characterization and application of cellular metals and metal foams", Progress in Materials Science, v. 46, n. 6, pp. 559-632, January 2000.

[7] ZHAO, D.X., SUN, Y.Y., "A novel sintering-dissolution process for manufacturing Al foams", Scripta Materialia, v. 44, n. 1, pp. 105-110, July 2000.

[8] BAFTI, H., HABIBOLAHZADEH, A., "Production of aluminum foam by spherical carbamide space holder technique-processing parameters", Materials Design, v. 31, n. 9, pp. 4122-4129, October 2010.

[9] JEE, C.S.Y., GUO, Z.X., et al, "Preparation of high porosity metal foams", Metallurgical Materials Transactions B., v. 31, n. 6, pp. 1345-1352, December 2000.

[10] HAO, G.L., HAN, F.S., LI, W.D. "Processing and mechanical properties of magnesium foams”, Journal of Porous Materials, v. 16, n. 3, pp. 251-256. June 2009.

[11] ZHAO, Y., HAN, F., FUNG, T., "Optimization of compaction and liquid-state sintering in sintering and dissolution process for manufacturing Al foams", Materials Science and Engineering A., v. 364, n. 1-2, pp. 117-125. January 2004. 
[12] ASTM Standard G1-90, "Standard practice for preparing, cleaning and evaluating corrosion test specimens", ASTM International, United States, 1999.

[13] LI, J.R., CHENG, H.F., et al, "Effect of dual-size cell mix on the stiffness and strength of open-cell aluminum foams", Materials Science and Engineering A., v. 362, n. 1-2, pp. 240-248. December 2003.

[14] BÁEZ PIMIENTO, S., HERNÁNDEZ ROJAS, M.E., PALOMAR PARDAVÉ, M.E. “ Device for sintering metallic compacted particles", Patent request at the Mexican Institute of Industrial Property, Mexico, July 2013.

[15] ASTM standard E9-89a, "Standard practice for compression testing of metallic materials at room temperature", ASTM International, United States, 2002. 